\title{
Functioning Pituitary Adenomas - Current Treatment Options and Emerging Medical Therapies
}

\author{
Elena V Varlamov, Shirley McCartney, Maria Fleseriu \\ Oregon Health \& Science University, Oregon, USA
}

$\mathrm{P}$ ituitary adenomas are benign tumours comprising approximately $16 \%$ of all primary cranial neoplasms. Functioning pituitary adenomas (prolactinomas, somatotroph, corticotroph, thyrotroph and rarely gonadotroph adenomas) cause complex clinical syndromes and require prompt treatment to reduce associated morbidity and mortality. Treatment approaches include transsphenoidal surgery, medical therapy and radiation. Medical therapy is the primary therapy for prolactinomas, and surgery by a skilled neurosurgeon is the first-line approach for other functioning pituitary adenomas. A multimodal treatment is frequently necessary to achieve biochemical and clinical control, especially, when surgery is not curative or when medical therapy fails. Several emerging, novel, medical treatments for acromegaly, Cushing's disease and prolactinomas are in phase II and III clinical trials and may become effective additions to the current drug armamentarium. The availability of various management options will allow an individualised treatment approach based on the unique tumour type, clinical situation and patient preference.

\section{Keywords}

Pituitary adenoma, prolactinoma, acromegaly, Cushing's disease, TSH-secreting adenoma, gonadotroph adenoma, transsphenoidal surgery, radiation, medical therapy

Disclosures: Maria Fleseriu has been a principa investigator for studies with research grants to Oregon Health \& Science University from Chiasma, Ionis, Millendo, Novartis, Pfizer and Strongbridge, and has been an occasional scientific consultant to Chiasma, Ionis, Ipsen, Novartis, Pfizer and Strongbridge. Elena $\vee$ Varlamov and Shirley McCartney have nothing to declare in relation to this article.

Compliance with Ethics: This article involves a review of the literature and did not involve any studies with human or animal subjects performed by any of the authors.

Review process: Double-blind peer review

Authorship: All named authors meet the criteria of the International Committee of Medical Journal Editors for authorship for this manuscript, take responsibility for the integrity of the work as a whole and have given final approval for the version to be published.

Received: 18 October 2018

Accepted: 11 February 2019

Citation: European Endocrinology. 2019:15(1):30-40

Corresponding author: Maria Fleseriu, Oregon Health \& Science University, CH8N, 3303 SW Bond Ave, Portland, Oregon, 97239. USA.E. fleseriu@ohsu.edu

Support: No funding was received for the publication of this article.
Pituitary adenomas are benign tumours that arise from the adenohypophysis. They are the second most frequent intracranial tumour type after meningiomas, and account for $16.2 \%$ of all primary cranial neoplasms. ${ }^{1}$ Though likely an underestimate, the incidence of pituitary adenomas is approximately four per 100,000 persons per year, ${ }^{2,3}$ and incidence increases with age. ${ }^{4}$ Prolactinomas and non-functioning pituitary adenomas are the most common pituitary adenoma types, followed by somatotroph, corticotroph and thyrotroph adenomas. Almost all gonadotroph adenomas are clinically non-functioning, and less than $1 \%$ are hormonally active. ${ }^{4,5}$ Functioning pituitary adenomas carry significant morbidity and increased mortality due to resultant clinical syndromes, concurrent hypopituitarism as well as tumour mass effect..$^{-8}$ Prompt and effective treatment is crucial to disease control and a reduction in associated health risks..$^{9-11}$ In this review, treatment options for different types of functioning pituitary adenomas are presented, with a focus on current and emerging medical therapies.

\section{Pituitary adenoma therapy}

Therapy for pituitary adenomas includes transsphenoidal surgery, medical treatment and/or radiation therapy.

\section{Surgery}

Transsphenoidal surgery is the first-line therapy for most cases of functioning pituitary adenomas (except prolactinomas), as surgery can achieve rapid and sustained biochemical remission, along with decompression of the optic chiasm. However, surgery carries the risk of new pituitary deficiencies (3.6-19.4\%), transient or permanent diabetes insipidus (4.3-17.7\% and $0.3-7.3 \%$ respectively), hyponatremia (4.3-21\%) and other surgical complications such as cerebrospinal fluid (CSF) leak (2.6-7\%), haemorrhage (1.1-2.9\%), infection (1.1-3.8\%), carotid artery injury $(0.1-1.1 \%)$ and vision loss $(0.6-1.8 \%) .^{12-14}$ In a meta-analysis, hypopituitarism was more common after transsphenoidal surgery for Cushing's disease (25\%) than acromegaly, prolactinoma or non-functioning pituitary adenomas (approximately 7-12\%), and is thought to be related to prolonged glucocorticoid replacement and a more aggressive surgical technique used for corticotroph adenomas. ${ }^{15}$ Rates of surgical success and complications vary, with more favourable outcomes achieved with experienced surgeons and in high-volume centres. ${ }^{13,16}$ Microscopic and endoscopic techniques appear equally effective, with a similar complication rate. 12,14

\section{Medical}

Medical therapy is generally used as adjunct therapy after a failed transsphenoidal surgery in Cushing's disease and acromegaly, when surgery cannot be performed, or for recurrent disease. Often medical therapy becomes a long-term treatment option that requires monitoring for biochemical control and side effects. Pituitary-directed medications (somatostatin receptor ligands 
[SRLS] and dopamine agonists) exert antisecretory and antiproliferative effects on pituitary tumours; prolactinomas typically respond to dopamine agonists with considerable tumour regression, while in acromegaly and Cushing's disease, tumour response to SRLS varies significantly. End-organ targeted therapy, such as inhibitors of adrenal steroidogenesis or receptor blockers, e.g. glucocorticoid or growth hormone receptor antagonists, can provide effective biochemical and/or clinical disease control (Table 1).

\section{Radiation}

Due to slow onset of response (up to several years) and development of new pituitary deficiencies, radiation therapy is considered a third-line therapy option following unsuccessful transsphenoidal surgery and failed

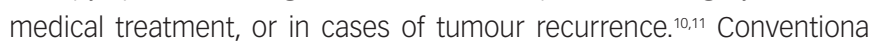
and stereotactic fractionated radiation is delivered in multiple smal doses over 5-6 weeks, while stereotactic radiosurgery is performed in a single-session, high-dose treatment. Conventional and stereotactic radiosurgery therapy have similar effectiveness, although stereotactic radiosurgery may result in quicker normalisation of hypersecreted hormones. ${ }^{17-19}$ Stereotactic radiosurgery is more convenient for a patient; however, it carries a higher risk of damage to the optic apparatus in tumours located very close to the optic chiasm. ${ }^{18-20}$ Secondary brain tumours develop in 1.1-2.4\% of patients after conventional therapy with relative risk ranging from no increased risk to 10.5 compared to the general population, and several studies have shown no increased risk compared to nonirradiated patients. ${ }^{21,22}$ Conventional radiotherapy may pose a slightly higher risk of stroke, especially in acromegaly, ${ }^{23}$ and it has been associated with neurocognitive impairment, specifically in verbal memory and executive function, regardless of tumour type. ${ }^{24}$

\section{Prolactinomas}

Prolactinomas are the most common functioning pituitary tumours $(66 \%)$, with a female:male ratio of 10:1.2,25 The majority are microadenomas (80\%) and men more commonly present with macroadenomas. ${ }^{2,26}$ Giant prolactinomas represent $1-5 \%$ of all prolactinomas. ${ }^{27}$

\section{Medical}

Dopamine agonists, the mainstay of medical therapy, are very effective at normalising prolactin levels and reducing pituitary adenoma size; resulting in a rapid, often within days, visual improvement and gradual restoration of hypogonadism and fertility. ${ }^{28,29}$ Cabergoline and bromocriptine are dopamine agonists available in the United States. Another dopamine agonist, quinagolide, is used in some European countries. Cabergoline is recommended over bromocriptine due to higher potency and effectiveness when compared with bromocriptine. ${ }^{28}$ Cabergoline normalises prolactin in $83 \%$ versus bromocriptine in $59 \%$ of women with hyperprolactinaemic amenorrhea. ${ }^{30} \mathrm{~A}$ meta-analysis of six observational studies and three randomised trials showed superiority of cabergoline at reducing prolactin levels and associated symptoms of hypogonadism in women. ${ }^{31}$ The effect on tumour volume reduction has not been assessed in randomised controlled trials. However, data extracted from two separate studies suggest greater efficacy of cabergoline on tumour volume reduction, $96 \%$ versus $64 \%$ with bromocriptine. ${ }^{32-34}$ This difference in efficacy is thought to be related to cabergoline having a stronger affinity for dopamine D2 receptors and a longer duration of action. ${ }^{28}$

Resistance, defined as inability to achieve normoprolactinaemia or $50 \%$ reduction in tumour volume with standard doses of dopamine agonist, occurs in $25 \%$ of patients treated with bromocriptine and $10 \%$ treated with cabergoline. ${ }^{28,35}$ It is estimated that up to $80 \%$ of those resistant to bromocriptine can achieve normal prolactin levels with cabergoline. ${ }^{28}$ The mechanism of resistance is also poorly understood, but may be due to decreased number of D2 receptors, presence of different receptor isoforms or downstream signalling changes in resistant prolactinomas. ${ }^{28,36,37}$ Cabergoline dose may be increased, typically (1-2 $\mathrm{mg} /$ week) to a maximal tolerable dose, though this is rarely reported to overcome resistance. ${ }^{28}$

Common side effects of dopamine agonists are nausea, dizziness and headache, with nausea being more pronounced in patients treated with bromocriptine. Additionally, there is growing evidence of an association of dopamine agonist use with impulse control disorders such as pathologic gambling and hypersexuality. ${ }^{38}$ Although the prevalence of these disorders in patients with prolactinomas is still unknown, one study reported that the risk of developing an impulse control disorder was 9.9 times higher in males treated with dopamine agonists compared to those with non-functioning adenomas. ${ }^{38,39}$ A very rare but serious complication is CSF leak in giant prolactinomas eroding the sellar floor, which typically requires urgent neurosurgical intervention..$^{40}$ Although standard cabergoline doses are not associated with increased risk of valvular heart disease, doses $>2 \mathrm{mg} /$ week and high cumulative doses may still carry some risk, and monitoring with echocardiograms has been recommended by some groups. ${ }^{41-45}$ Few studies have reported association of bromocriptine with non-clinically significant valve fibrosis, ${ }^{46,47}$ and larger studies have reported no association. ${ }^{43}$

Investigation of emerging medical therapies is underway (Table 2). Lapatinib is a tyrosine-kinase inhibitor of epidermal growth factor receptor (EGFR) and receptor tyrosine-protein kinase (ErbB2 or human epidermal growth factor receptor 2 [HER2]), which shows promise as a treatment for resistant prolactinomas. Lapatinib has been demonstrated to decrease prolactin levels by $60 \%$ and $40 \%$ in transgenic mice with pituitary expression of EGFR and HER2, respectively; prolactin remained unaltered in control mice. ${ }^{48}$ In two human subjects, addition of lapatinib to cabergoline after prolonged treatment with high dose cabergoline allowed for $22 \%$ tumour volume reduction and almost normalisation of prolactin at 6 months in one case, and suppression of tumour growth with $42 \%$ prolactin reduction in the other case. ${ }^{49,50}$ Side effects were mild alopecia, rash, diarrhoea and anorexia. Lapatinib is currently being evaluated in the phase II trial, Targeted Therapy with Lapatinib in Patients with Recurrent Pituitary Tumors Resistant to Standard Therapy (ClinicalTrials.gov Identifier; NCT00939523).

\section{Surgery}

Transsphenoidal surgery is reserved for patients with resistant prolactinomas, those with intolerance or contraindications to medical therapy, as well as emergent situations such as apoplexy and CSF leak. Several studies have examined the outcomes of transsphenoidal surgery and reported variable remission rates; range 30-93\%, ${ }^{51}$ with lower remission rates reported for invasive prolactinomas. Following transsphenoidal surgery, new pituitary deficiencies developed in $17.1 \%$ of patients in one study (7.0\% anterior pituitary hypofunction), while improvement of existing deficiencies occurred in 14.6\%.52 Although prolactinomas in men tend to be more aggressive, it has not been clearly demonstrated that men have poorer surgical outcomes. ${ }^{26,53}$ However, a recent study of prolactinomas in males who required surgery reported a high rate of residual tumour (92.6\%) and frequent need for additional surgery and radiation. ${ }^{26}$ Preoperative dopamine-agonist therapy does not appear to significantly affect surgical cure. $26,51,53$ Following debulking surgery, medical therapy normalises prolactin levels in almost half of resistant adenomas, and with lower dopamine agonists doses. ${ }^{51}$ 
Table 1: Current medical options for prolactinoma, acromegaly and Cushing's disease

\begin{tabular}{|c|c|c|c|}
\hline \multirow[b]{2}{*}{$\begin{array}{l}\text { Disease treatment, medication } \\
\text { and dose }\end{array}$} & \multicolumn{3}{|l|}{ Medication } \\
\hline & Class & Advantages & Notes of special interest \\
\hline \multicolumn{4}{|l|}{ Prolactinomas } \\
\hline $\begin{array}{l}\text { Cabergoline } \\
\bullet 0.25-1 \mathrm{mg} / \text { twice weekly, oral }\end{array}$ & D2 receptor agonist & $\begin{array}{l}\text { - More effective and better } \\
\text { tolerated than bromocriptine } \\
\text { - Longer acting, allowing twice } \\
\text { weekly dosing }\end{array}$ & $\begin{array}{l}\text { - Higher doses, average } 3-4 \mathrm{mg} / \text { week, may be needed for } \\
\text { resistant prolactinomas } \\
\text { - In a few patients, up to } 7-11 \mathrm{mg} / \text { week have been reported, } \\
\text { but efficacy and safety is unknown } \\
\text { - May require echocardiography to monitor for valvular } \\
\text { defects if used in high doses for prolonged period of time }\end{array}$ \\
\hline $\begin{array}{l}\text { Bromocriptine } \\
\text { - } 2.5-15 \mathrm{mg} / \text { day, oral; may } \\
\text { divide into } 2 x \text { day dosing }\end{array}$ & D2 receptor agonist & $\begin{array}{l}\text { - Preferred in pregnancy (more } \\
\text { safety data than with cabergoline) } \\
\text { - Less expensive }\end{array}$ & $\begin{array}{l}\text { - Causes more nausea than cabergoline } \\
\text { - Less effective than cabergoline }\end{array}$ \\
\hline \multicolumn{4}{|l|}{ Acromegaly } \\
\hline $\begin{array}{l}\text { Octreotide SC } \\
\text { - } 50-100 \mu \mathrm{\mu g} / 3 \mathrm{x} \text { day, SC }\end{array}$ & $\begin{array}{l}\text { Somatostatin receptor } \\
\text { ligand }\end{array}$ & $\begin{array}{l}\text { - May be used in addition to long- } \\
\text { acting SRLs to treat acromegaly- } \\
\text { associated headaches }\end{array}$ & - Short acting, requires multiple daily injections \\
\hline $\begin{array}{l}\text { Octreotide LAR } \\
\text { - } 10-40 \mathrm{mg} / \mathrm{month}, \mathrm{IM}\end{array}$ & $\begin{array}{l}\text { Somatostatin receptor } \\
\text { ligand }\end{array}$ & & $\begin{array}{l}\text { - In the US, can only be administered by a healthcare } \\
\text { professional }\end{array}$ \\
\hline $\begin{array}{l}\text { Lanreotide } \\
\text { - } 60-120 \mathrm{mg} / \mathrm{month} \text {, deep SC }\end{array}$ & $\begin{array}{l}\text { Somatostatin receptor } \\
\text { ligand }\end{array}$ & $\begin{array}{l}\text { - Packaged in prefilled syringes, } \\
\text { can be self-administered }\end{array}$ & $\begin{array}{l}\text { - Some patients develop subcutaneous nodules at injection } \\
\text { site }\end{array}$ \\
\hline $\begin{array}{l}\text { Pasireotide LAR } \\
\text { - } 40-60 \mathrm{mg} / \text { month, SC }\end{array}$ & $\begin{array}{l}\text { Somatostatin receptor } \\
\text { ligand, higher SSTR5 } \\
\text { affinity }\end{array}$ & - More efficacious than octreotide & $\begin{array}{l}\text { - Causes hyperglycaemia in more than half of patients and } \\
\text { glucose needs to be closely monitored } \\
\text { - QTC prolongation } \\
\text { - LFT elevation }\end{array}$ \\
\hline $\begin{array}{l}\text { Cabergoline } \\
\text { - } 0.5-2 \mathrm{mg} / \text { week, oral }\end{array}$ & D2 receptor agonist & - Oral route & $\begin{array}{l}\text { - Higher doses have been reported but unlikely to be } \\
\text { beneficial } \\
\text { - Less effective than somatostatin receptor ligands, used } \\
\text { mostly in combination therapies }\end{array}$ \\
\hline $\begin{array}{l}\text { Pegvisomant } \\
\text { - } 10-40 \mathrm{mg} / \text { day, SC }\end{array}$ & GH receptor antagonist & $\begin{array}{l}\text { - Highly effective } \\
\text { - Improves insulin resistance }\end{array}$ & $\begin{array}{l}\text { - Does not have anti-tumour effect } \\
\text { - Cannot use GH to monitor disease control }\end{array}$ \\
\hline \multicolumn{4}{|l|}{ Cushing's disease } \\
\hline \multicolumn{4}{|l|}{ Pituitary-directed drugs } \\
\hline $\begin{array}{l}\text { Pasireotide } \\
\text { - } 0.3-0.9 \mathrm{mg} / 2 \mathrm{x} \text { day, SC }\end{array}$ & $\begin{array}{l}\text { Somatostatin receptor } \\
\text { ligand, higher SSTR5 } \\
\text { affinity }\end{array}$ & $\begin{array}{l}\text { - Anti-tumour effect with tumour } \\
\text { shrinkage in some patients }\end{array}$ & $\begin{array}{l}\text { - Controls mild-to-moderate hypercortisolism, less effective } \\
\text { for severe disease } \\
\text { - Causes hyperglycaemia }\end{array}$ \\
\hline $\begin{array}{l}\text { Pasireotide LAR } \\
\text { - } 10-40 \mathrm{mg} / \mathrm{month}, \mathrm{SC}\end{array}$ & $\begin{array}{l}\text { Somatostatin receptor } \\
\text { ligand, higher SSTR5 } \\
\text { affinity }\end{array}$ & $\begin{array}{l}\text { - Anti-tumour effect with tumour } \\
\text { shrinkage in some patients } \\
\text { - Monthly administration }\end{array}$ & $\begin{array}{l}\text { - Controls mild-to-moderate hypercortisolism, less effective } \\
\text { for severe disease } \\
\text { - Causes hyperglycaemia }\end{array}$ \\
\hline $\begin{array}{l}\text { Cabergoline } \\
\text { - } 0.5-7 \mathrm{mg} / \text { week, oral }\end{array}$ & D2 receptor agonist & - Possible anti-tumour effect & $\begin{array}{l}\text { - Usually used only in combination with other drugs } \\
\text { - Risk of treatment escape }\end{array}$ \\
\hline \multicolumn{4}{|l|}{ Inhibitors of adrenal steroidogenesis } \\
\hline $\begin{array}{l}\text { Ketoconazole } \\
\text { - } 400-1,200 \text { mg/day, oral; } \\
\text { divided into 2-4 doses }\end{array}$ & $\begin{array}{l}\text { Inhibitor of CYP17A1, } \\
\text { CYP11A1 and CYP11B1 }\end{array}$ & $\begin{array}{l}\text { - Rapid effect } \\
\text { - Relatively inexpensive }\end{array}$ & $\begin{array}{l}\text { - No anti-tumour effect } \\
\text { - Multiple daily dosing } \\
\text { - Interaction with many drugs }\end{array}$ \\
\hline $\begin{array}{l}\text { Metyrapone } \\
\text { - } 0.5-6.0 \text { g/day oral; divided into } \\
4 \text { doses }\end{array}$ & $\begin{array}{l}\text { Inhibitor of CYP11B1, } \\
\text { CYP11B2 and CYP17A1 }\end{array}$ & $\begin{array}{l}\text { - Rapid effect } \\
\text { - Limited availability in most } \\
\text { countries }\end{array}$ & $\begin{array}{l}\text { - No anti-tumour effect } \\
\text { - Multiple daily dosing }\end{array}$ \\
\hline $\begin{array}{l}\text { Mitotane } \\
\text { - 2-4 g/day oral; divided into } \\
\text { 3-4 doses }\end{array}$ & $\begin{array}{l}\text { Inhibitor of CYP11A1, } \\
\text { CYP11B1 and CYP11B2 }\end{array}$ & - Very potent & $\begin{array}{l}\text { - No anti-tumour effect } \\
\text { - Slow onset of effect } \\
\text { - Usually requires steroid replacement }\end{array}$ \\
\hline $\begin{array}{l}\text { Etomidate } \\
\text { - } 0.03 \mathrm{mg} / \mathrm{kg} \text { bolus, followed by } \\
0.02-0.08 \mathrm{mg} / \mathrm{kg} / \mathrm{hr}\end{array}$ & $\begin{array}{l}\text { Inhibitor of CYP11B1, } \\
\text { CYP17A1 and CYP11A1 }\end{array}$ & $\begin{array}{l}\text { - Rapid effect } \\
\text { - Can be used short term for } \\
\text { severe hypercortisolism }\end{array}$ & $\begin{array}{l}\text { - No anti-tumour effect } \\
\text { - IV, requires monitoring in ICU }\end{array}$ \\
\hline \multicolumn{4}{|l|}{ Glucocorticoid receptor blockers } \\
\hline $\begin{array}{l}\text { Mifepristone } \\
\text { - 300-1,200 mg/day, oral }\end{array}$ & $\begin{array}{l}\text { GC receptor antagonist; } \\
\text { antiprogestin }\end{array}$ & $\begin{array}{l}\text { - Effective for hyperglycaemia } \\
\text { in Cushing's syndrome }\end{array}$ & $\begin{array}{l}\text { - No anti-tumour effect } \\
\text { - Dose adjustment only based on clinical grounds (cannot } \\
\text { follow cortisol levels) }\end{array}$ \\
\hline
\end{tabular}

$D=$ diarrhoea; $D 2$ = dopamine receptor D2; GC = glucocorticoid; $G H=$ growth hormone; ICU = intensive care unit; IM = intramuscular; $I V=$ intravenous; $L F T=$ liver function test; $S R L=$ somatostatin receptor ligand; SSTR5 = somatostatin receptor 5; SC = subcutaneous; $V=$ vomiting. QTC= electrocardiogram calculated duration of time from the start of the $Q$ wave to the end of the $T$ wave adjusted for a patient's heart rate. 
Table 2: Emerging investigational drug medical therapies for pituitary adenomas

\begin{tabular}{|c|c|c|c|c|c|}
\hline Name & Class & $\begin{array}{l}\text { Dosage/route/ } \\
\text { schedule }\end{array}$ & Side effects & Notes / current testing phase & $\begin{array}{l}\text { ClinicalTrials.gov } \\
\text { number or } \\
\text { reference }\end{array}$ \\
\hline \multicolumn{6}{|l|}{ Prolactinomas } \\
\hline Lapatinib & Tyrosine-kinase inhibitor & 1,250 mg PO daily & $\begin{array}{l}\text { Fatigue, nausea, diarrhoea, } \\
\text { paraesthesias, insomnia }\end{array}$ & $\begin{array}{l}\text { May be effective for resistant } \\
\text { prolactinomas } \\
\text { Phase ॥ }\end{array}$ & NCT00939523 \\
\hline \multicolumn{6}{|l|}{ Acromegaly } \\
\hline Oral octreotide & Somatostatin receptor ligand & $\begin{array}{l}\text { 20-40 mg PO twice } \\
\text { daily }\end{array}$ & $\begin{array}{l}\text { Nausea, vomiting, diarrhoea, } \\
\text { dyspepsia, cholelithiasis, } \\
\text { headaches, dizziness, } \\
\text { dysglycemia }\end{array}$ & $\begin{array}{l}\text { Oral route } \\
\text { Phase III }\end{array}$ & $\begin{array}{l}\text { NCT02685709 } \\
\text { NCT03252353 }\end{array}$ \\
\hline ATL1103 & $\begin{array}{l}\text { Antisense oligonucleotide } \\
\text { inhibitor of growth hormone } \\
\text { receptor }\end{array}$ & $\begin{array}{l}200 \text { mg SC once or } \\
\text { twice weekly }\end{array}$ & $\begin{array}{l}\text { Injection site reaction, LFT } \\
\text { elevation, headache }\end{array}$ & Completed phase II & $\begin{array}{l}\text { Trainer et al., } \\
2018^{108}\end{array}$ \\
\hline ISIS 766720 & $\begin{array}{l}\text { Antisense oligonucleotide } \\
\text { inhibitor of growth hormone } \\
\text { receptor, in liver }\end{array}$ & $\begin{array}{l}\text { 60-80 mg SC every } 4 \\
\text { weeks }\end{array}$ & To be determined & Phase II & NCT03548415 \\
\hline CRN00808 & $\begin{array}{l}\text { Somatostatin receptor } 2 \text { biased } \\
\text { agonist }\end{array}$ & PO once daily & Not available & Phase ॥ & NCT03789656 \\
\hline Raloxifene & $\begin{array}{l}\text { Selective oestrogen receptor } \\
\text { modulator (partial oestrogen } \\
\text { agonist in bone and cardiovascular } \\
\text { system; anti-oestrogen in } \\
\text { endometrial and breast tissues) }\end{array}$ & 60 mg PO twice daily & $\begin{array}{l}\text { Flushing, leg cramps, } \\
\text { peripheral oedema, venous } \\
\text { thromboembolism }\end{array}$ & $\begin{array}{l}\text { Studied as adjuvant therapy } \\
\text { in men, postmenopausal } \\
\text { women and hypogonadal } \\
\text { premenopausal women }\end{array}$ & Imani et al., $2018^{106}$ \\
\hline Tamoxifen & $\begin{array}{l}\text { Selective oestrogen receptor } \\
\text { modulator (oestrogen agonist in } \\
\text { bone, cardiovascular system, and } \\
\text { endometrial tissue; anti-oestrogen } \\
\text { in breast tissue) }\end{array}$ & 20-40 mg PO daily & $\begin{array}{l}\text { Hot flushes, venous } \\
\text { thromboembolism, } \\
\text { endometrial cancer }\end{array}$ & $\begin{array}{l}\text { Studied as adjuvant therapy } \\
\text { in men and postmenopausal } \\
\text { women }\end{array}$ & $\begin{array}{l}\text { Balili and Barkan, } \\
2014^{104}\end{array}$ \\
\hline Clomiphene & $\begin{array}{l}\text { Selective oestrogen receptor } \\
\text { modulator (blocks central } \\
\text { oestrogen receptors causing } \\
\text { increase of LH and FSH; weak } \\
\text { oestrogen agonist on periphery) }\end{array}$ & 50 mg PO daily & $\begin{array}{l}\text { Hot flushes, headaches, } \\
\text { dizziness, gynecomastia }\end{array}$ & $\begin{array}{l}\text { Studied as adjuvant therapy } \\
\text { in men }\end{array}$ & $\begin{array}{l}\text { Duarte et al., } \\
2015^{105}\end{array}$ \\
\hline \multicolumn{6}{|l|}{ Cushings Disease } \\
\hline \multicolumn{6}{|l|}{ Pituitary directed } \\
\hline Roscovitine & $\begin{array}{l}\text { Cyclin-dependent kinase 2/cyclin } \\
\text { E inhibitor }\end{array}$ & 400 mg PO twice daily & $\begin{array}{l}\text { Weakness, nausea, vomiting, } \\
\text { hypokalaemia }\end{array}$ & Phase II & NCT02160730 \\
\hline Gefitinib & $\begin{array}{l}\text { Epidermal growth factor receptor } \\
\text { inhibitor }\end{array}$ & 250 mg PO daily & $\begin{array}{l}\text { Dermatologic, diarrhoea, } \\
\text { weakness, LFT elevation }\end{array}$ & $\begin{array}{l}\text { Targets USP8-mutated } \\
\text { adenomas } \\
\text { Oral } \\
\text { Phase II }\end{array}$ & NCT02484755 \\
\hline Retinoic acid & Retinoic acid receptor agonist & 80 mg PO daily & Nausea, headache, arthralgia & $\begin{array}{l}\text { Anti-tumour effect in animal } \\
\text { studies }\end{array}$ & $\begin{array}{l}\text { Pecori Giraldi et al., } \\
2012^{156} \\
\text { Vilar et al., } 2016^{157}\end{array}$ \\
\hline \multicolumn{6}{|c|}{ Inhibitors of adrenal steroidogenesis } \\
\hline Levoketoconazole & $\begin{array}{l}\text { Inhibitor of cytochrome P450: } \\
-\quad \text { CYP17A1 } \\
-\quad \text { CYP11A1 } \\
-\quad \text { CYP11B1 } \\
-\quad \text { CYP21A2 }\end{array}$ & $\begin{array}{l}\text { 200-1200 mg PO twice } \\
\text { daily }\end{array}$ & $\begin{array}{l}\text { Headache, back pain, nausea, } \\
\text { LFT elevation, } \\
\text { QTC prolongation }\end{array}$ & $\begin{array}{l}\text { More potent than } \\
\text { ketoconazole } \\
\text { Phase III }\end{array}$ & NCT03277690 \\
\hline Osilodrostat & $\begin{array}{l}\text { Inhibitor of cytochrome P450: } \\
\text { - } \quad \text { CYP11B2 } \\
\text { - } \quad \text { CYP11B1 at higher doses }\end{array}$ & 2-30 mg PO twice daily & $\begin{array}{l}\text { Nausea, diarrhoea, asthenia, } \\
\text { adrenal insufficiency, } \\
\text { hirsutism, acne, headache, } \\
\text { hypokalaemia }\end{array}$ & $\begin{array}{l}\text { Very effective in phase II } \\
\text { clinical trial } \\
\text { Phase III }\end{array}$ & NCT02697734 \\
\hline ATR -101 & $\begin{array}{l}\text { Acetyl-CoA Acetyltransferase } 1 \\
\text { inhibitor }\end{array}$ & $\begin{array}{l}\text { 125-1000 mg PO } \\
\text { twice daily }\end{array}$ & $\begin{array}{l}\text { Vomiting, diarrhoea } \\
\text { in animal study }\end{array}$ & Phase II & NCT03053271 \\
\hline \multicolumn{6}{|c|}{ Glucocorticoid receptor blockers } \\
\hline Relacorilant & Glucocorticoid receptor antagonist & 100-400 mg PO daily & $\begin{array}{l}\text { Headache, nausea, vomiting, } \\
\text { thirst, musculoskeletal pain }\end{array}$ & $\begin{array}{l}\text { No antiprogestin properties } \\
\text { Phase II }\end{array}$ & NCT02804750 \\
\hline
\end{tabular}


Recurrence of hyperprolactinaemia after initial remission following transsphenoidal surgery is common, reportedly varying between $5-58 \%$; higher rates are reported in studies with longer follow up. ${ }^{51,52,54}$

\section{Radiation}

Radiation therapy is used for resistant and aggressive or malignant prolactinomas. ${ }^{55}$ Prolactin levels normalise in $26-52 \%$ of patients post radiation therapy, tumour growth is controlled in $89-92 \%{ }^{55-57}$ and hypopituitarism occurs in one-third of patients. ${ }^{55}$ Some authors have reported that dopamine agonist use at the time of radiation may reduce remission rates, while others did not find this association. ${ }^{55,58,59}$ Therefore, there is no universal recommendation to withhold dopamine agonists prior to radiation.

\section{Acromegaly}

Growth hormone-producing adenomas represent approximately 9.0-13.2\% of pituitary adenomas; $73.0 \%$ are macroadenomas, ${ }^{25,60}$ and giant adenomas constitute about $4.5 \%{ }^{27}$ Acromegaly affects males and females equally and is most commonly diagnosed during the fifth decade of life. ${ }^{61}$

\section{Surgery}

Transsphenoidal surgery is recommended as the first-line treatment due to rapid control of growth hormone levels. When performed by an experienced surgeon, remission is greater than $85 \%$ for microadenomas ${ }^{62,63}$ and $40-66 \%$ for macroadenomas. ${ }^{63,64}$ If biochemical remission is not achieved, patients require adjunctive medical therapy and/or radiation therapy. Even when the likelihood of cure is low, such as in the case of large or invasive adenomas, debulking surgery is still recommended as it provides better postoperative control by SRLS. ${ }^{65-8}$ Five-year recurrence after surgery is reported as $0.7-5.4 \%$ in various studies, and 10-15-year recurrence as $0.1-10 \% .64,69-71$ Incidence of pituitary deficiencies after transsphenoidal surgery include $6.50 \%$ for adrenal insufficiency, $4.39 \%$ for central hypothyroidism, $6.70 \%$ for hypogonadism, $14.95 \%$ for growth hormone deficiency and $10.05 \%$ for transient and $2.42 \%$ for permanent diabetes insipidus, as assessed by a meta-analysis. $^{72}$

Overall, surgery is more effective than primary medical therapy for treatment-naïve patients. A meta-analysis of prospective and retrospective studies demonstrated that surgically treated patients had higher remission rates than their medically treated counterparts $(67 \%$ versus $45 \%, p=0.02)^{73}$

Finally, surgery can provide additional information about tumour granulation type and presence of somatostatin receptor (SSTR) on pathology. Densely granulated adenomas and SSTR2A-positive adenomas respond better to SRLS than sparsely granulated adenomas and SSTR2A-negative adenomas. ${ }^{74,75}$ This knowledge allows for an SRL response prediction, which serves to guide physicians in selecting individualised patient treatment plans (e.g. SRL monotherapy versus pegvisomant or early combination therapy).

\section{Medical}

Medical therapy may be used as primary therapy in poor candidates for surgery, in those who decline surgery or if surgery is unlikely to provide biochemical cure due to extent of the disease..$^{10}$ Occasionally, medical therapy is used preoperatively in high-risk patients with a goal of reducing growth hormone levels and decreasing anaesthesia complications such as laryngeal oedema, high-output heart failure and uncontrolled hypertension. ${ }^{76,77}$ SRLS, growth hormone receptor antagonists (pegvisomant) and dopamine agonists are the three classes of medications currently used to treat acromegaly. They are used as a single agent or in combination. ${ }^{7.78}$

SRLS act on SSTR subtypes 2 and 5 located on somatotroph cells. First-generation SRLS (octreotide [OCT] long-acting release [LAR], lanreotide slow release and lanreotide autogel) seem to be equally effective in controlling growth hormone and insulin-like growth factor 1 (IGF-1) level in approximately 55\% of patients (reported clinical studies range $17-70 \%$ ). 10,79,80 The wide range in reported efficacy can be explained by different clinical study methodology, selection bias, previous surgery or medical treatment, dose, duration of follow-up and other factors. ${ }^{79}$ Biochemical control can be maximised by escalating the dose of OCT-LAR (60 mg every 4 weeks) ${ }^{81}$ and lanreotide (180 mg every 4 weeks or $120 \mathrm{mg}$ every 3 weeks) in treatment-responsive patients. ${ }^{22-84}$ First-generation SRLS are effective at shrinking the tumour in 30-66\% of patients by $10-77 \% .{ }^{85-87}$ Approximately one-third of patients experience $50 \%$ tumour volume reduction with primary medical therapy. ${ }^{86}$ Common side effects include gastrointestinal distress, gallstones and dysglycaemia.

Pasireotide is a multi-SRL with a high affinity for SSTR5 compared to other SRLS and has been demonstrated to have higher efficacy than OCT-LAR in a randomised controlled trial (31.3\% versus $19.2 \%$, respectively, $\mathrm{p}=0.007$ ), while tumour volume reduction was similar, approximately $40 \%{ }^{88}$ Additionally, pasireotide can normalise biochemical control in $20 \%$ of patients resistant to first-generation SRLS; ${ }^{89}$ however, hyperglycaemia occurs in $57 \%$ of patients. Pasireotide-induced hyperglycaemia has been attributed to a reduction in insulin secretion, glucagon-like peptide-1 (GLP-1) and glucose-dependent insulinotropic polypeptide levels. ${ }^{90}$ Close monitoring in patients with impaired glucose tolerance and diabetes is required and treatment with metformin, dipeptidyl peptidase-4 (DPP-4) inhibitor or GLP-1 receptor agonist has been recommended for the management of hyperglycaemia.91

Pegvisomant is a highly selective growth hormone receptor antagonist that blocks growth hormone receptor to reduce IGF-1 production by the liver. Pegvisomant is used in patients who remained uncontrolled after transsphenoidal surgery or radiation therapy and sometimes as primary therapy if transsphenoidal surgery is not feasible or desired..$^{10,92}$ In clinical trials, pegvisomant effectiveness was remarkable, with IGF-1 normalisation rates of up to $97 \%$ on maximal doses of $40 \mathrm{mg}$ daily. ${ }^{93}$ However, long-term surveillance studies indicated that a real-world control rate was approximately $60 \%$, likely reflecting lower standard doses used in everyday practice compared with clinical trials. ${ }^{10,82}$ Liver function tests are monitored and treatment should be discontinued if transaminases increase to greater than five-times the upper limit of normal (ULN). Despite a theoretical concern that lack of IGF-1 feedback may stimulate pituitary tumour growth, progression of tumour was noted only in $3 \%$ of patients. ${ }^{94}$ Although this may represent natural tumour progression independent of pegvisomant, serial magnetic resonance imaging (MRI) has been recommended. ${ }^{10}$

Dopamine agonists normalise IGF-1 and growth hormone in one-third of patients, ${ }^{95,96}$ and induce tumour volume reduction in up to $62 \% .{ }^{95}$ Due to modest efficacy in acromegaly, cabergoline plays a role mostly as adjunctive therapy in cases with mildly elevated IGF-1.

\section{Combination medical therapy}

Pegvisomant can be used in combination with first-generation SRLS in patients who are uncontrolled on SRL alone. This may result in IGF-1 normalisation in up to $95 \%$ of cases. $^{97}$ A combination of 
pegvisomant and pasireotide may potentially allow for lower doses. This has been examined in one study to date, 98,99 where it was demonstrated that switching from first-generation SRLS to pasireotide allowed for a reduction in pegvisomant dose by half. Pegvisomant did not offset or prevent pasireotide-induced hyperglycaemia. Diarrhoea was a common side effect, but no elevation of transaminases was observed.

Dopamine agonists in combination with SRLS achieve normalised IGF-1 levels in approximately half of patients who are uncontrolled on SRLS alone..$^{95}$ Cabergoline plus a low-dose pegvisomant combination is also a modestly effective option when liver enzyme elevation, diabetes or SRL-induced hyperglycaemia is a concern. ${ }^{100}$

Oestrogen is capable of lowering IGF-1 through inhibition of liver growth hormone receptor expression or through upregulation of suppressors of cytokine signalling-2, leading to decreased growth hormone signalling. ${ }^{101,102}$ Selective oestrogen receptor modulators bind to oestrogen receptors and exhibit oestrogen agonistic or antagonistic effects in different tissues. Raloxifene, tamoxifen and clomiphene have been studied as an add-on therapy in men and post-menopausal women with uncontrolled acromegaly. ${ }^{103-106}$ In one study, tamoxifen normalised IGF-1 in eight (47\%) patients and decreased IGF-1 in 14 (82\%) patients. ${ }^{104} \mathrm{~A}$ recent head-to-head open label study of raloxifene versus cabergoline add-on therapy to long-acting SRL showed similar lowering effect on IGF-1; IGF-1 normalised in $45.5 \%$ of patients with raloxifene and in $40.9 \%$ of patients with cabergoline. ${ }^{106}$ Adverse effects included flushing. A study of clomiphene in men has shown a decrease in IGF-1 by $41 \%$, including normalisation of IGF-1 in $44 \%$ without reported side effects. ${ }^{105}$ Selective oestrogen receptor modulators are not part of standard acromegaly management and longer-term studies are needed to assess their safety and efficacy. ${ }^{106}$

\section{Emerging medical therapy}

Several new acromegaly treatment agents as well as a new SRL formulations are being tested in human clinical trials (Table 2). In a phase III clinical trial, oral OCT maintained biochemical control in $62 \%$ of patients who were switched from a long-acting SRL (from $89 \%$ controlled on SRL at baseline). ${ }^{107}$ There are two other ongoing phase III trials: Comparison of Oral Octreotide Capsules to Injectable Somatostatin Analogs in Acromegaly (MPOWERED; ClinicalTrials.gov Identifier: NCT02685709) and Efficacy and Safety of Octreotide Capsules (MYCAPSSA) in Acromegaly (OPTIMAL; ClinicalTrials.gov Identifier: NCT03252353).

An antisense oligonucleotide inhibitor of growth hormone receptors is a novel and promising therapy. A phase II study of ATL1103 demonstrated a $27.8 \%$ reduction of IGF-1 at week 14 , with good tolerability but mild-to-moderate injection-site reaction occurring in 85\%. ${ }^{108} \mathrm{~A}$ newer generation antisense oligonucleotide ISIS 766720, targeting hepatic expression of growth hormone receptor, is currently being investigated in a phase II trial (Safety, Tolerability, and Efficacy of IONIS-GHRLRx in up to 42 Adult Patients with Acromegaly Being Treated with Long-acting Somatostatin Receptor Ligands; ClinicalTrials.gov Identifier: NCT03548415)

Another emerging therapeutic agent is an orally bioavailable nonpeptide SSTR2 biased agonist, CRN00808. CRN00808 is biased for SSTR2 activation (a process that causes reduction of growth hormone secretion) over receptor internalisation (which is a process that limits therapeutic activity of SSTR agonist). Preliminary phase I clinical trial data (Single and Multiple-Ascending Dose Study of CRN00808 in Healthy Volunteers; ClinicalTrials.gov Identifier: NCT03276858) show that a $2.5 \mathrm{mg}$ once-daily dose lowers growth hormone-releasing hormone-induced growth hormone release by $73 \%$ in healthy volunteers. ${ }^{109}$ A phase II study evaluating CRN00808 in patients with acromegaly treated with SRLS is ongoing (A Study to Evaluate the Safety and Efficacy of CRN00808 for the Treatment of Acromegaly [ACROBAT EDGE]; ClinicalTrials.gov Identifier: NCT03789656).

\section{Radiation}

Radiation therapy is reserved for patients with persistent disease after surgery who failed medical therapy. However, remission onset is slow, taking many years and requiring medical therapy in the interim. Hormonal remission rates are $50-60 \%$ at $10-15$ years with both stereotactic radiosurgery and conventional radiation, with stereotactic radiosurgery slightly more effective. ${ }^{23,10,111}$ Hypopituitarism develops in up to $50 \%$ of patients at 5 years. ${ }^{23,110}$ Some suggested that SRLs may prevent a full effect of radiation, but this has not been a consistent observation and may be due to the fact that in non-randomised studies, patients with more severe disease were more likely to continue SRL prior to treatment.. ${ }^{20,12,113}$ Although not clearly recommended by current guidelines, some centres withhold SRLS for four to eight weeks prior to radiation therapy. ${ }^{20}$

\section{Cushing's disease}

Adrenocorticotropic hormone (ACTH)-producing adenomas represent $4-6 \%$ of all adenomas, occurring more frequently in females (3:1 ratio). ${ }^{2,5}$ Only about a third are macroadenomas, while the majority are microadenomas, and approximately $12 \%$ of those are not detectable on MRI. ${ }^{5,14}$ Aggressive corticotroph adenomas are usually biochemically silent, and have an approximately $30 \%$ risk of recurrence. ${ }^{115}$

\section{Surgery}

Transsphenoidal surgery is the recommended treatment of choice for ACTH-producing adenomas. Remission rates range from 65-98\%, with higher rates when a pituitary adenoma is identified on MRI and removed completely by an experienced and specialised surgeon. ${ }^{16,117}$ If a pituitary adenoma is not found during surgical exploration, hemi-hypophysectomy/pan-hypophysectomy may be performed, with remission rates reported as $60-75 \% .{ }^{116}$ However, more extensive transsphenoidal surgery carries greater risk of hypopituitarism. Postoperative pituitary deficiencies develop in $25 \%$ of patients with Cushing's disease compared to approximately $7-13 \%$ in other pituitary adenomas. ${ }^{15}$ Transient diabetes insipidus is the most common postoperative pituitary dysfunction occurring in $4-48 \%$ of patients, while permanent diabetes insipidus has been reported in 3-46\% of patients. ${ }^{15,118}$ Rates of postoperative thyrotropin and gonadotropin deficiency are $11-20 \%$ and $8-17 \%$ respectively. ${ }^{118-120}$ In one study, prevalence of growth hormone deficiency was $65 \%$ in patients who achieved long-term surgical remission. ${ }^{121}$

Failure of remission occurs when a pituitary adenoma is incompletely excised or missed on surgical exploration, if dural invasion is present, or if a pituitary adenoma is extra-pituitary. ${ }^{16,122,123}$ Repeat surgery is an option for those with persistent hypercortisolism; however, remission rates are lower, $57-71 \% .{ }^{124,125}$ Given the possibility of delayed remission, the decision to repeat surgery should be postponed until persistent disease is biochemically confirmed. Hypercortisolism can recur in up to $35 \%$ of cases. ${ }^{116,126}$

\section{Medical}

Medical therapy is necessary for persistent or recurrent hypercortisolism after transsphenoidal surgery or if surgery is contraindicated or declined. Additionally, medical therapy can be used post-radiation therapy until 
radiation effect occurs. Current medical therapy is directed at three targets: ACTH production by a corticotroph tumour, steroidogenesis in the adrenal gland, and glucocorticoid receptors.

Pituitary-directed drugs include pasireotide and cabergoline. Pasireotide binds to SSTR5 receptor, which is predominantly expressed on corticotroph adenoma cells, and inhibits ACTH production. In a 12-month clinical trial of pasireotide in Cushing's disease, subcutaneous pasireotide decreased urinary free cortisol (UFC) by approximately $50 \%$ and normalised levels in more than $20 \%$ of patients, mainly in those with mild-to-moderate cortisol hypersecretion. Tumour volume reduction was $43 \%$ on a maximum dose of $900 \mu \mathrm{g}$ daily. ${ }^{127}$ A long-acting monthly intramuscular formulation, pasireotide LAR, is available and has a similar efficacy as the subcutaneous pasireotide. ${ }^{128}$ The most frequent side effect of both formulations is hyperglycaemia, occurring in more than half of patients. Gastrointestinal side effects such as nausea, diarrhoea and cholelithiasis are similar in frequency to other SRLS. ${ }^{127}$ Cabergoline acts via D2 receptors on cortocotroph tumours. It is mostly used as an add-on therapy. Short-term response with UFC normalisation is observed in 25-35\% of patients, ${ }^{129-131}$ while long-term efficacy is lower, mainly due to treatment escape. ${ }^{129,132}$ The dose range is 1-7 mg/week, with a commonly used dose of 2-3.5 mg/week.

Currently available inhibitors of steroidogenesis are ketoconazole, metyrapone, mitotane and etomidate. Ketoconazole is an antifungal agent used off-label in the United States (licensed in Europe) for Cushing's syndrome. Ketoconazole inhibits cytochrome P450 enzymes on multiple levels of steroidogenesis and at higher doses effectively lowers glucocorticoid and androgen synthesis. ${ }^{133}$ Studies report efficacy in $30-90 \%$ of patients. The largest retrospective study to date showed that $49 \%$ of patients with Cushing's disease achieved normal UFC and $25 \%$ had at least $50 \%$ reduction in UFC; however, $15 \%$ experienced escape from control after 2 years of treatment. ${ }^{134-7}$ Severe ketoconazole-induced hepatotoxicity (black box warning in the United States) is rare; however, mild liver enzyme elevation is relatively common and therefore requires close monitoring. ${ }^{138}$ Gynecomastia and hypogonadism due to inhibition of androgen synthesis limits use in males.

Metyrapone can effectively lower cortisol in $43-76 \%$ of patients with Cushing's syndrome without apparent escape. ${ }^{139}$ Blockade of 11-beta hydroxylase causes accumulation of mineralocorticoid and androgenic precursors resulting in hypertension, hypokalaemia, oedema, hirsutism and acne. Mild gastrointestinal symptoms are common. Mitotane plays a major role in the treatment of adrenal carcinoma due to its adrenolytic effect on tumour cells, but it is occasionally used in Cushing's disease. Very potent, but with a slow onset of action, mitotane induces eucortisolaemia in $72-82 \%$ of patients ${ }^{11}$ and often leads to adrenal insufficiency, requiring hydrocortisone replacement. side effects include gastrointestinal upset, lethargy and abnormal liver function. Etomidate is a parenteral anaesthetic, which at lower, sub-hypnotic doses, rapidly inhibits cortisol production and thus has been used in patients with severe Cushing's syndrome in the acute setting as well as preoperatively to decrease the risk of hypercortisolaemia related complications. ${ }^{140}$

Mifepristone is a glucocorticoid receptor antagonist that has been shown to significantly improve clinical manifestations of Cushing's syndrome, including glucose metabolism, hypertension and weight gain.
Overall, a clinical response was observed in up to $87 \%$ of patients. ${ }^{141}$ However, its mechanism of action causes ACTH and cortisol levels to rise during treatment, and therefore, they cannot be used to guide management; caution is required for potential tumour enlargement, especially in the case of macroadenomas. ${ }^{142}$ When encountered, adrenal insufficiency due to glucocorticoid receptor blockade should be treated with high doses of dexamethasone. Additionally, unopposed mineralocorticoid activity of cortisol can cause hypertension, oedema and hypokalaemia. The latter can be ameliorated by use of the mineralocorticoid blocker spironolactone. Also, an antiprogestin effect may result in endometrial hyperplasia. ${ }^{143}$

\section{Combination medical therapy}

combination therapy is increasingly used for those patients who have failed monotherapy or if side effects of a single agent do not permit a dose increase. Regimens such as pasireotide plus cabergoline, ketoconazole plus cabergoline, and ketoconazole plus metyrapone have been successfully utilised. ${ }^{144,145}$

\section{Emerging medical therapy}

Multiple new medical therapies are currently in development and are undergoing clinical testing (Table 2). New inhibitors of steroidogenesis include levoketoconazole, osilodrostat and ATR-101.

Levoketoconazole is a more potent enantiomer of ketoconazole and was proposed to achieve similar effectiveness with smaller doses and less pronounced side effects than ketoconazole. In a phase III, open-label trial, $81 \%$ of patients had initial UFC normalisation at the end of the dose titration period (up to 21 weeks), but only $30 \%$ of patients had normal UFC levels during the maintenance phase without a dose increase. ${ }^{146}$ Nausea and headache were most common side effects and liver function test elevation of $>3$ ULN in $11 \%$ of patients is relatively similar to the ketoconazole data from retrospective and observational data, although the studies are not comparable. ${ }^{139}$ Levoketoconazole is currently being assessed in a phase III, double-blind, withdrawal and rescue/restoration study (A Study to Assess the Safety and Efficacy of Levoketoconazole in the Treatment of Endogenous Cushing's Syndrome; ClinicalTrials.gov Identifier: NCT03277690).

Osilodrostat is an oral nonsteroidal corticosteroid biosynthesis inhibitor that inhibits 11 beta-hydroxylase with higher affinity than metyrapone and has a longer half-life. ${ }^{147}$ In an open label study, osilodrostat induced normalisation of UFC in $84 \%$ of patients at week 10 and $79 \%$ at week 22. ${ }^{148}$ Despite the increase in the precursor 11-deoxycorticosterone, hypokalaemia was mild and hypertension has not been observed. Hirsutism and acne occurred in one-third of women due to elevated testosterone. Two phase III studies are ongoing: Safety and Efficacy of LCl699 for the Treatment of Patients with Cushing's Disease (ClinicalTrials.gov Identifier: NCT02180217) and Efficacy and Safety Evaluation of Osilodrostat in Cushing's Disease (LINC-4) (ClinicalTrials.gov Identifier: NCT02697734).

ATR-101, is a selective acyl-coenzyme A:cholesterol acyltransferase 1 (ACAT1)1 inhibitor that reduces cholesterol ester formation from cholesterol, thereby decreasing the substrate supply for steroidogenesis in the adrenal glands. ATR-101 was shown to reduce cortisol level by $50 \%$ in animal studies and is currently being studied in a phase II, double-blind study in humans (A Study of ATR-101 for the Treatment of Endogenous Cushing's Syndrome; ClinicalTrials.gov Identifier: NCT03053271). 
Relacorilant (CORT125134) is a selective antiglucocorticoid receptor antagonist that has an advantage of avoiding the progesterone receptor inhibitory effects of mifepristone. A phase II trial is ongoing (Study to Evaluate CORT125134 in Patients with Cushing's Syndrome, ClinicalTrials.gov Identifier: NCT02804750). Preliminary results of the low-dose arm showed improvement in glucose control, blood pressure, marker of bone formation and, somewhat surprisingly, a relatively small increase in $\mathrm{ACTH}$ and cortisol. ${ }^{149}$

Pituitary-targeted therapies in phase $\|$ trials include roscovitine and gefitinib. Roscovitine is a cyclin-dependent kinase inhibitor that suppresses 2/cyclin E on corticotroph tumour cells causing inhibition of the ACTH precursor hormone, proopiomelanocortin (POMC), with a subsequent decrease of $\mathrm{ACTH}$ production, although with a minimal antiproliferative effect. ${ }^{150}$ It is currently studied in a dose of $400 \mathrm{mg}$ orally twice daily for 4 days every week, for a total of 4 weeks in Cushing's disease (Treatment of Cushing's Disease with R-roscovitine; ClinicalTrials.gov Identifier: NCT02160730).

Roscovitine has also been assessed in phase I trials in patients with various malignant solid tumours; some showed stabilisation of growth. ${ }^{151,152}$ Side effects were dose dependent and included fatigue, skin rash, hyponatremia and hypokalaemia occurring at doses of $800 \mathrm{mg}$ and higher. ${ }^{151}$ Gefitinib is an EGFR inhibitor approved for non-small cell lung cancer. EGF binds to EGFR on corticotroph tumour cells and promotes POMC and ACTH synthesis. ${ }^{152}$ Approximately half of corticotroph tumours harbour a somatic USP8 mutation which causes over-expression of EGFR. ${ }^{153}$ Gefitinib has been shown to inhibit ACTH production in USP8-mutated corticotroph tumours. ${ }^{76,152} \mathrm{~A}$ study of gefitinib $250 \mathrm{mg}$ once daily for 4 weeks is ongoing (Targeted Therapy with Gefitinib in Patients with USP8-mutated Cushing's Disease; ClinicalTrials.gov Identifier: NCT02484755). Common adverse events are rash, diarrhoea and elevation of liver enzymes. ${ }^{153}$ Interstitial lung disease of grade $3-4$ occurs in $0.7 \%$ of patients (package insert). ${ }^{154}$ Other mutations harboured by corticotroph tumours (e.g. USP48 and BRAF) are being actively investigated, but are beyond the scope of this review. ${ }^{155}$

Retinoic acid decreases ACTH by suppressing pro-opiomelanocortin gene transcription and exerts an anti-tumour effect in corticotroph adenomas. ${ }^{156}$ In a small prospective study, retinoic acid at $80 \mathrm{mg}$ daily for 6-12months decreased UFC to $22-73 \%$ of baseline levels; however, some patients were non-responders. ${ }^{156}$ Another small study (16 patients) showed a normalisation of UFC in $25 \%$ of participants at study end..$^{15}$

Emerging pituitary-targeted drug treatments not yet in clinical trials include heat shock protein inhibitors, histone deacetylase inhibitors, monoclonal ACTH antibodies and others. ${ }^{158,159}$

\section{Radiation}

Radiation therapy is used when pituitary surgery is unsuccessful, in invasive adenomas or in poor surgical candidates. All patients should receive medical treatment while awaiting radiation effects, which may take several years. Control of hypercortisolism is achieved in up to $83 \%$ of patients undergoing conventional radiation and $70 \%$ undergoing stereotactic radiosurgery. ${ }^{18,160}$ Time to remission with stereotactic radiosurgery appears to be shorter, 14.5 months versus 18.0-42.0 months with conventional radiation. ${ }^{161}$ Recurrence after initial control has been observed in $18 \%$ of patients after stereotactic radiosurgery, which confirms the need for lifelong monitoring. ${ }^{161}$

\section{Bilateral adrenalectomy}

Bilateral adrenalectomy is reserved as a third-line treatment option for patients with uncontrolled hypercortisolism despite pituitary surgery, appropriate medical therapy and/or pituitary radiation. It can be life-saving in patients with severe and prolonged Cushing's syndrome who require rapid and permanent control of hypercortisolism. ${ }^{162,163}$ Lastly, it may be selected earlier in patients desiring fertility options in whom pituitary irradiation or surgery is likely to result in irreversible hypogonadism. Rarely, hypercortisolism may persist or recur due to remnant adrenal tissue. Corticotroph tumour progression (Nelson's syndrome) occurs in $0-47 \%$ of patients post bilateral adrenalectomy, ${ }^{16,165}$ and some data suggest that prior pituitary radiation may reduce the risk. ${ }^{16,167}$ It is important to periodically monitor $\mathrm{ACTH}$ and pituitary MRI. Mortality in the first year seems to be high post bilateral adrenalectomy. ${ }^{164}$

\section{Thyroid stimulating hormone-secreting adenomas}

Thyroid stimulating hormone (TSH)-secreting adenomas are rare, 0.5-3.0\% of all pituitary adenomas, with equal male-female distribution, and are mostly macroadenomas at diagnosis. ${ }^{168}$ Surgical resection is the first-line treatment, with remission rates of $55-83 \% .{ }^{169,170}$ Complete surgical removal is often impossible due to the fibrotic nature of these tumours and parasellar extension/invasion, necessitating adjunct medical therapy and/or radiation. ${ }^{168}$ Pre-treatment with antithyroid drugs, beta-blockers and SRLS is necessary in some cases to control severe hyperthyroidism to reduce the risk of perioperative thyroid storm. ${ }^{169,171}$ In a series of 68 operated patients (67\% macroadenomas), six patients (9\%) developed new hypopituitarism; hypogonadism in two, hypoadrenalism in two, both hypoadrenalism and hypogonadism in one, and panhypopituitarism in one patient. ${ }^{169} \mathrm{~A}$ smaller series of 13 patients reported postoperative hypopituitarism in five patients (38\%); hypoadrenalism in three, hypothyroidism in one, growth hormone deficiency in two and hypogonadism in one patient. ${ }^{172}$ Radiation for persistent disease controls hyperthyroidism in $20-50 \%$ and produces tumour volume reduction in $26 \%$ of patients, and hypopituitarism occurs in approximately one-third of patients. ${ }^{169}$

Octreotide and lanreotide reduce TSH and normalise thyroid hormone levels in more than $80 \%$ patients. 169,173 In a study of pre-operative OCT-LAR for a median of 33.5 days, T4 normalisation occurred in $84 \%$ of patients. ${ }^{172}$ Another study of mixed patient population (post pituitary surgery with or without additional radiation or medical therapy and those who were treatment-naïve) showed that lanreotide was effective at normalising thyroid hormone levels in $81 \%$ of patients. ${ }^{174}$ Resistance and escape from therapy are uncommon. As marked suppression of thyroid function can occur, patients should be monitored for hypothyroidism. SRLS induce tumour shrinkage in $39-61 \%$ of patients. ${ }^{171,174}$ Although TSH-secreting tumours express D2 receptors, dopamine agonists are less effective, with favourable results observed mostly in mixed prolactin/TSH-secreting adenomas. ${ }^{168,175}$

\section{Gonadotroph adenomas}

Functioning gonadotroph adenomas are very rare and treatment algorithms are limited to case reports and small case series. Adenomectomy is, however, the principal treatment approach; it restores gonadal function in men and women, and leads to the resolution of ovarian and testicular enlargement caused by hyperstimulation by gonadotroph adenoma. ${ }^{176}$ Radiation has been used as adjunct therapy 
after surgery, as well as for recurrent adenomas. ${ }^{177-180}$ Dopamine agonists, SRLS, gonadotropin-releasing hormone agonists and antagonists have been tried both as primary therapy and after transsphenoidal surgery, and in the majority of cases showed no benefit for clinical symptoms or tumour shrinkage. ${ }^{176}$

\section{Aggressive pituitary adenomas}

Aggressive pituitary adenomas are those that exhibit clinically significant growth despite appropriate medical, surgical and radiation therapy. ${ }^{181}$ They are often characterised by an elevated Ki68 index ( $\geq 3-10 \%$, high p53 immunoreactivity and increased number of mitoses; however, these criteria have not been validated as strong prognostic markers of aggressiveness. Debulking surgery or neartotal resection is recommended, especially for tumours with masseffect on optic chiasm. Radiation therapy following surgery should be considered in patients without contraindication to radiation therapy, as it can provide a durable control of tumour growth. Medical therapy usually includes the use of temozolomide, an alkylating agent, alone or in combination with standard medical therapy for functioning pituitary adenomas (dopamine agonist, SRLS). ${ }^{182,183}$ Temozolomide is typically administered in cycles of 5 days every 28 days, with a maximum number of cycles of 9-12. Response rate (tumour shrinkage) differs by tumour type and is estimated from a small case series to be $44 \%$ in prolactinomas, $56 \%$ in corticotroph tumours, $38 \%$ in somatotroph tumours and only $22 \%$ in non-functioning tumours. ${ }^{182}$ Absent or low expression of 06-methylguanine-DNA methyltransferase, a DNA repair enzyme that interferes with temozolomide action, has been correlated with better response to temozolomide by some, but not all, authors. ${ }^{184,185}$ Temozolomide is usually well tolerated; however, myelosuppression can occur. ${ }^{185}$

\section{Conclusion}

Management of functioning pituitary adenomas often requires multiple treatment modalities to achieve rapid and durable remission and thus improve morbidity, mortality and quality of life. Treatment should be tailored individually based on the tumour type, availability of each therapeutic option and patient preference. Emerging medical therapies are being developed and may present future suitable options for patients with uncontrolled disease or intolerance to other medications.
1. Ostrom QT, Gittleman $\mathrm{H}$, Liao P, et al. CBTRUS Statistical Report: Primary brain and other central nervous system tumors diagnosed in the United States in 2010-2014. Neuro Oncol. 2017:19 Suppl. 5:1-88.

2. Daly AF, Rixhon M, Adam C, et al. High prevalence of pituitary adenomas: A cross-sectional study in the province of Liege, Belgium. J Clin Endocrinol Metab. 2006:91:4769-75.

3. Fernandez A, Karavitaki N, Wass JA. Prevalence of pituitary adenomas: A community-based, cross-sectional study in Banbury (Oxfordshire, UK). Clin Endocrinol (Oxf). 2010;72:37782.

4. Aflorei ED, Korbonits M. Epidemiology and etiopathogenesis of pituitary adenomas. J Neurooncol. 2014;117:379-94.

Tjornstrand A, Gunnarsson K, Evert M, et al. The incidence rate of pituitary adenomas in western Sweden for the period 20012011. Eur J Endocrinol. 2014;171:519-26.

6. Jasim S, Alahdab F, Ahmed AT, et al. Mortality in adults with hypopituitarism: A systematic review and meta-analysis. Endocrine. 2017;56:33-42.

Melmed S. Acromegaly pathogenesis and treatment. J Clin Invest. 2009;119:3189-3202.

8. Dekkers OM, Horvath-Puho E, Jorgensen JO, et al. Multisystem morbidity and mortality in Cushing's syndrome: A cohort study. I Clin Endocrinol Metab. 2013;98:2277-84.

9. Fleseriu M, Hashim IA, Karavitaki N, et al. Hormonal replacement in hypopituitarism in adults: An Endocrine Society clinical practice guideline. I Clin Endocrinol Metab. 2016;101:3888-3921.

10. Katznelson $L$, Laws ER Jr, Melmed S, et al. Acromegaly: An Endocrine Society clinical practice guideline. I Clin Endocrinol Metab. 2014;99:3933-51.

11. Nieman LK, Biller BM, Findling JW, et al. Treatment of Cushing's syndrome: An Endocrine Society clinical practice guideline. J Syndrome: An Endocrine Society clinical p

12. Agam MS, Wedemeyer MA, Wrobel B, et al. Complications associated with microscopic and endoscopic transsphenoidal pituitary surgery: Experience of 1153 consecutive cases treated at a single tertiary care pituitary center. J Neurosurg. 2018:1-8.

3. Ciric I, Ragin A, Baumgartner C, Pierce D. Complications of transsphenoidal surgery: Results of a national survey, review of the literature, and personal experience. Neurosurgery. 1997;40:225-36.

14. Ammirati M, Wei L, Ciric I. Short-term outcome of endoscopic versus microscopic pituitary adenoma surgery: A systematic review and meta-analysis. J Neurol Neurosurg Psychiatry 2013;84:843-9.

15. Roelfsema F, Biermasz NR, Pereira AM. Clinical factors involved in the recurrence of pituitary adenomas after surgical remission: A structured review and meta-analysis. Pituitary. 2012;15:71-83.

16. Barker FG 2nd, Klibanski A, Swearingen B. Transsphenoidal surgery for pituitary tumors in the United States, 1996-2000: Mortality, morbidity, and the effects of hospital and surgeon volume. J Clin Endocrinol Metab. 2003;88:4709-19.

17. Mitsumori M, Shrieve DC, Alexander E 3rd, et al. Initial clinical results of LINAC-based stereotactic radiosurgery and stereotactic radiotherapy for pituitary adenomas. Int $J$ Radiat Oncol Biol Phys. 1998;42:573-80

18. Sheehan JP, XU Z, Salvetti DJ, et al. Results of gamma knife surgery for Cushing's disease. J Neurosurg. 2013;119:1486-92.

19. Lee CC, Vance ML, Xu Z, et al. Stereotactic radiosurgery for acromegaly. J Clin Endocrinol Metab. 2014;99:1273-81. acromegaly. J Clin Endocrinol Metab. 2014;99:1273-81. radiosurgery for acromegaly: An international multicenter radiosurgery for acromegaly: An international multicenter
retrospective cohort study. Neurosurgery. 2019;84:717-25.

21. Minniti G, Traish D, Ashley S, et al. Risk of second brain tumor after conservative surgery and radiotherapy for pituitary adenoma: Update after an additional 10 years. I Clin Endocrino adenoma: Update after

22. van Varsseveld $\mathrm{NC}$, van Bunderen $\mathrm{CC}$, Ubachs $\mathrm{DH}$, et al.
Cerebrovascular events, secondary intracranial tumors, and mortality after radiotherapy for nonfunctioning pituitary adenomas: A subanalysis from the Dutch National Registry of Growth Hormone Treatment in Adults. I Clin Endocrinol Metab. 2015:100:1104-12.

23. Gheorghiu ML. Updates in outcomes of stereotactic radiation therapy in acromegaly. Pituitary. 2017;20:154-68.

24. Lecumberri B, Estrada J, Garcia-Uria J, et al. Neurocognitive long-term impact of two-field conventional radiotherapy in adult patients with operated pituitary adenomas. Pituitary. 2015;18:782-95.

25. Gillam MP, Molitch ME, Lombardi G, Colao A. Advances in the treatment of prolactinomas. Endocr Rev. 2006;27:485-534.

26. Liu W, Zahr RS, McCartney S, et al. Clinical outcomes in male patients with lactotroph adenomas who required pituitary surgery: A retrospective single center study. Pituitary. 2018; 21:454-62.

27. Shimon I, Jallad RS, Fleseriu M, et al. Giant GH-secreting pituitary adenomas: management of rare and aggressive pituitary tumors. Eur J Endocrinol. 2015;172:707-713.

28. Melmed S, Casanueva FF, Hoffman AR, et al. Diagnosis and treatment of hyperprolactinemia: An Endocrine Society clinica practice guideline. J Clin Endocrinol Metab. 2011;96:273-88.

29. Moster ML, Savino PJ, Schatz NJ, et al. Visual function in prolactinoma patients treated with bromocriptine. Ophthalmology. 1985;92:1332-41.

30. Webster J, Piscitelli G, Polli A, et al. A comparison of cabergolin and bromocriptine in the treatment of hyperprolactinemic amenorrhea. Cabergoline Comparative Study Group. N Eng/ J Med. 1994;331:904-9.

31. Wang AT, Mullan RJ, Lane MA, et al. Treatment of hyperprolactinemia: A systematic review and meta-analysis. hyperprolactinemia; A
Syst Rev. 2012;1:33.

32. Colao A, Di Sarno A, Landi ML, et al. Macroprolactinoma shrinkage during cabergoline treatment is greater in naive patients than in patients pretreated with other dopamine agonists: A prospective study in 110 patients. I Clin Endocrino Metab 2000:85:2247-52.

33. Molitch ME, Elton RL, Blackwell RE, et al. Bromocriptine as primary therapy for prolactin-secreting macroadenomas: Results of a prospective multicenter study. I Clin Endocrino Metab. 1985;60:698-705.

34. Molitch ME. Management of medically refractory prolactinom J Neurooncol. 2014;117:421-8.

35. Berinder K, Stackenas I, Akre O, et al. Hyperprolactinaemia in 271 women: up to three decades of clinical follow-up. Clir Endocrinol (OXf). 2005;63:450-5

36. Kukstas $L A$, Domec $C$, Bascles $L$, et al. Different expression of the two dopaminergic D2 receptors, D2415 and D2444, in two types of lactotroph each characterised by their response to dopamine, and modification of expression by sex steroids. Endocrinology. 1991;129:1101-3.

37. Pellegrini I, Rasolonjanahary R, Gunz G, et al. Resistance to bromocriptine in prolactinomas. I Clin Endocrinol Metab. 1989;69:500-9

38. Noronha S, Stokes V, Karavitaki N, Grossman A. Treating prolactinomas with dopamine agonists: Always worth the gamble? Endocrine. 2016;51:205-10

39. Bancos I, Nannenga MR, Bostwick JM, et al. Impulse contro disorders in patients with dopamine agonist-treated prolactinomas and nonfunctioning pituitary adenomas: A casecontrol study. Clin Endocrinol (Oxf). 2014;80:863-8.

40. Chapin W, Yedinak C, Delashaw J, Fleseriu M. Cabergolineinduced cerebral spinal fluid leak in a patient with a large induced cerebral spinal fluid leak in a patient with a large

41. Vallette S, Serri K, Rivera J, et al. Long-term cabergoline therapy is not associated with valvular heart disease in patients with prolactinomas. Pituitary 2009:12:153-7.

42. Wakil A, Rigby AS, Clark AL, et al. Low dose cabergoline for hyperprolactinaemia is not associated with clinically significant valvular heart disease. Eur J Endocrinol. 2008;159:R11-14.

3. Drake WM, Stiles CE, Howlett TA, et al. A cross-sectional study of the prevalence of cardiac valvular abnormalities in hyperprolactinemic patients treated with ergot-derived dopamine agonists. J Clin Endocrinol Metab. 2014;99:90-6.

Caputo C, Prior D, Inder WJ. The third case of cabergolineassociated valvulopathy: The value of routine cardiovas
examination for screening. J Endocr Soc. 2018:2:965-9.

45. Gamble D, Fairley R, Harvey R, et al. Screening for valve disease in patients with hyperprolactinaemia disorders prescribed cabergoline: A service evaluation and literature review. Ther Adv Drug Saf. 2017;8:215-29.

46. Elenkova A, Shabani R, Kalinov K, Zacharieva S. Increased prevalence of subclinical cardiac valve fibrosis in patients with prolactinomas on long-term bromocriptine and cabergoline treatment. Eur J Endocrinol. 2012;167:17-25.

47. Boguszewski CL, dos Santos CM, Sakamoto KS, et al. A comparison of cabergoline and bromocriptine on the risk of valvular heart disease in patients with prolactinomas. Pituitary. 2012;15:44-9.

48. Liu X, Kano M, Araki T, et al. ErbB receptor-driven prolactinomas respond to targeted lapatinib treatment in female transgenic mice. Endocrinology. 2015;156:71-9.

49. Ben-Shlomo A, Cooper O. Role of tyrosine kinase inhibitors in the treatment of pituitary tumours: From bench to bedside. Curr Opin Endocrinol Diabetes Obes. 2017;24:301-5.

50. Cooper O, Mamelak A, Bannykh S, et al. Prolactinoma ErbB receptor expression and targeted therapy for aggressive tumors. Endocrine. 2014;46:318-27.

51. Primeau V, Raftopoulos C, Maiter D. Outcomes of transsphenoidal surgery in prolactinomas: improvement of hormonal control in dopamine agonist-resistant patients. Eur J Endocrinol. 2012;166:779-86.

52. Kreutzer J, Buslei $\mathrm{R}$, Wallaschofski $\mathrm{H}$, et al. Operative treatment of prolactinomas: Indications and results in a current consecutive series of 212 patients. Eur J Endocrinol. current consecutive

53. Qu X, Wang M, Wang G, et al. Surgical outcomes and prognostic actors of transsphenoidal surgery for prolactinoma in men: A single-center experience with 87 Endocrinol. 2011;164:499-504.

54. Serri $\mathrm{O}$, Rasio E, Beauregard $\mathrm{H}$, et al. Recurrence of hyperprolactinemia after selective transsphenoidal adenomectomy in women with prolactinoma. N EngI I Med. 1983;309:280-3

55. Cohen-Inbar O, Xu Z, Schlesinger D, et al. Gamma knife radiosurgery for medically and surgically refractory prolactinomas: Long-term results. Pituitary. 2015;18:820-30.

. Pan L, Zhang N, Wang EM, et al. Gamma knife radiosurgery as a primary treatment for prolactinomas. J Neurosurg. 2000;93 Suppl. 3:10-13.

57. Pouratian N, Sheehan J, Jagannathan J, et al. Gamma knife radiosurgery for medically and surgically refractory prolactinomas. Neurosurgery. 2006;59:255-66.

58. Jezkova J, Hana V, Krsek M, et al. Use of the Leksell gamma knife in the treatment of prolactinoma patients. Clin Endocrino (Oxf). 2009;70:732-41.

59. Sheplan Olsen $\mathrm{L}$, Robles Irizarry L, Chao ST, et al. Radiotherapy for prolactin-secreting pituitary tumors. Pituitary. 2012;15:13545.

60. Mestron A, Webb SM, Astorga R, et al. Epidemiology, clinical characteristics, outcome, morbidity and mortality in acromegaly

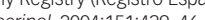

61. Lacrota

61. LavrentakiA, Paluzzi A, Wass JA, Karavitaki N. Epidemiolog of acromegaly. Review of population studies. Pituitary. 2017;20:4-9;

62. Jane JA Jr, Starke RM, Elzoghby MA, et al. Endoscopic transsphenoidal surgery for acromegaly: remission using
modern criteria, complications, and predictors of outcome. $J$ 
Clin Endocrinol Metab. 2011;96:2732-40.

63. Starke RM, Raper DMS, Payne SC, et al. Endoscopic vs microsurgical transsphenoidal surgery for acromegaly: Outcomes in a concurrent series of patients using modern criteria for remission. J Clin Endocrinol Metab. 2013;98:3190-8.

64. Nomikos P, Buchfelder M, Fahlbusch R. The outcome of surgery in 668 patients with acromegaly using current criteria of
biochemical 'cure'. Eur J Endocrinol. 2005; 152:379-87.

65. Karavitaki $\mathrm{N}$, Turner $\mathrm{HE}$, Adams $\mathrm{CB}$, et al. Surgical debulking of pituitary macroadenomas causing acromegaly improves control by lanreotide. Clin Endocrinol (Oxf). 2008;68:970-5.

66. Petrossians P, Borges-Martins L, Espinoza C, et al. Gross total resection or debulking of pituitary adenomas improves hormonal control of acromegaly by somatostatin analogs. Eur Endocrinol. 2005:152:61-6.

67. Fahlbusch R, Kleinberg D, Biller B, et al. Surgical debulking of pituitary adenomas improves responsiveness to octreotide la in the treatment of acromegaly. Pituitary. 2017;20:668-75.

68. Gheorghiu ML, Galoiu S, Vintila M, et al. Beneficial effect of dose escalation and surgical debulking in patients with acromegaly treated with somatostatin analogs in a Romanian tertiary care center. Hormones (Athens). 2016;15:224-34

69. Fernandez Mateos C, Garcia-Uria M, Morante TL, GarciaUria J. Acromegaly: Surgical results in 548 patients. Pituitary. 2017;20:522-8.

70. Freda PU, Wardlaw SL, Post KD. Long-term endocrinological follow-up evaluation in 115 patients who underwent transsphenoidal surgery for acromegaly. J Neurosurg. 1998;89:353-8.

71. Swearingen B, Barker FG 2nd, Katznelson L, et al. Long-term mortality after transsphenoidal surgery and adjunctive therapy for acromegaly. J Clin Endocrinol Metab. 1998;83:3419-26.

72. Carvalho P, Lau E, Carvalho D. Surgery induced hypopituitarism in acromegalic patients: A systematic review and meta-analysis of the results. Pituitary. 2015;18:844-60.

73. Abu Dabrh AM, Mohammed K, Asi N, et al. Surgical interventions and medical treatments in treatment-naive patients with acromegaly: Systematic review and metaanalysis. J Clin Endocrinol Metab. 2014;99:4003-14.

74. Brzana J, Yedinak CG, Gultekin SH, et al. Growth hormone granulation pattern and somatostatin receptor subtype $2 \mathrm{~A}$ correlate with postoperative somatostatin receptor ligand response in acromegaly: A large single center experience. Pituitary. 2012;16:490-8.

75. Fougner SL, Casar-Borota O, Heck A, et al. Adenoma granulation pattern correlates with clinical variables and effect of somatostatin analogue treatment in a large series of patients with acromegaly. Clin Endocrinol (OXf). 2011;76:96-102.

76. Fleseriu M, Hoffman AR, Katznelson L, AACE Neuroendocrine and Pituitary Scientific Committee. American Association of Clinical Endocrinologists and American College of Endocrinology Disease State Clinical Review: Management of acromegaly patients: What is the role of pre-operative medical acromegaly patients: What is the role of
therapy? Endocr Pract. 2015;21:668-73.

77. Gadelha MR, Kasuki L, Lim DS, Fleseriu M. Systemic complications of acromegaly and the impact of the current treatment landscape: An update Endocr Rev 2019:40:268-332.

78. Fleseriu M. Advances in the pharmacotherapy of patients with acromegaly. Discov med. 2014;17:329-38.

79. Carmichael JD, Bonert VS, Nuno M, et al. Acromegaly clinical trial methodology impact on reported biochemical efficacy rates of somatostatin receptor ligand treatments: A m analysis. J Clin Endocrinol Metab. 2014;99:1825-33.
8. Cozzi R, Montini M, Attanasio R, et al. Primary treatment of acromegaly with octreotide LAR: A long-term (up to nine years) prospective study of its efficacy in the control of disease activity and tumor shrinkage. J Clin Endocrinol Metab. 2006;91:1397-1403.

81. Giustina A, Bonadonna S, Bugari G, et al. High-dose intramuscular octreotide in patients with acromegaly inadequately controlled on conventional somatostatin analogue therapy: A randomised controlled trial. Eur J Endocrinol. 2009:161:331-8.

82. Melmed S, Bronstein MD, Chanson P, et al. A consensus statement on acromegaly therapeutic outcomes. Nat Rev Endocrinol. 2018;14:552-61.

83. Fleseriu M. Clinical efficacy and safety results for dose escalation of somatostatin receptor ligands in patients with acromegaly: A literature review. Pituitary. 2011;14:184-93.

84. Giustina A, Mazziotti G, Cannavo S, et al. High-dose and highfrequency lanreotide autogel in acromegaly: A randomized, multicenter study. I Clin Endocrinol Metab. 2017;102:2454-64.

85. Giustina A Mazziotti G, Torri V et al. Meta-analysis on the effects of octreotide on tumor mass in acromegaly. PloS one. 2012; : $:$ 36411.

86. Melmed S, Sternberg R, Cook D, et al. A critical analysis of pituitary tumor shrinkage during primary medical therapy in acromegaly. J Clin Endocrinol Metab. 2005;90:4405-10.

87. Mazziotti G, Glustina A. Effects of lanreotide SR and autogel on tumor mass in patients with acromegaly: A systematic review. Pituitary. 2010;13:60-7.

88. Colao A, Bronstein MD, Freda P, et al. Pasireotide versus octreotide in acromegaly: A head-to-head superiority study. Clin Endocrinol Metab. 2014;99:791-9.

89. Gadelha MR, Bronstein MD, Brue T, et al. Pasireotide versus continued treatment with octreotide or lanreotide in patients with inadequately controlled acromegaly (PAOLA) A randomised, phase III trial. Lancet Diabetes Endocrinol. 2014;2:875-84.

90. Henry RR, Ciaraldi TP, Armstrong D, et al. Hyperglycemia associated with pasireotide: Results from a mechanistic study in healthy volunteers. J Clin Endocrinol Metab. 2013;98:344653.

91. Samson SL. Management of hyperglycemia in patients with 43.

92. Tritos NA, Chanson P, Jimenez C, et al. Effectiveness of first-line pegvisomant monotherapy in acromegaly: An ACROSTUDY analysis. Eur J Endocrinol. 2017;176:213-20.
93. van der Lely AJ, Hutson RK, Trainer PJ, et al. Long-term treatment of acromegaly with pegvisomant, a growth hormone receptor antagonist. Lancet. 2001;358:1754-9.

94. van der Lely AJ, Biller BM, Brue T, et al. Long-term safety of pegvisomant in patients with acromegaly: Comprehensive review of 1288 subjects in ACROSTUDY. $J$ Clin Endocrinol Metab. 2012;97:1589-97.

95. Sandret L, Maison P, Chanson P. Place of cabergoline in acromegaly: A meta-analysis. J Clin Endocrinol Metab. 2011;96:1327-35

9. Sherlock M, Fernandez-Rodriguez E, Alonso AA, et al. Medical therapy in patients with acromegaly: Predictors of response and comparison of efficacy of dopamine agonists
and somatostatin analogues. J Clin Endocrinol Metab. 2009;94:1255-63.

97. van der Lely AJ, Bernabeu I, Cap J, et al. Coadministration of lanreotide autogel and pegvisomant normalizes IGF1 levels and is well tolerated in patients with acromegaly partially controlled by som

98. Muhammad A, Coopmans EC, Delhanty P, et al. Efficacy and safety of switching to pasireotide in acromegaly patients controlled with pegvisomant and somatostatin analogues: Controlled with pegvisomant and somatostatin analogues:

99. Muhammad A, van der Lely AJ, Delhanty PJD, et al. Efficacy and safety of switching to pasireotide in patients with acromegaly controlled with pegvisomant and first-generation somatostatin analogues (PAPE study). I Clin Endocrinol Metab. 2018:103:586-95.

100. Higham CE, Atkinson AB, Aylwin S, et al. Effective combination treatment with cabergoline and low-dose pegvisomant in active acromegaly: A prospective clinical trial. J Clin Endocrinol Metab. 2012;97:1187-93.

101. Domene HM, Marin G, Sztein J, et al. Estradiol inhibits growth hormone receptor gene expression in rabbit liver. Mol Cell Endocrinol. 1994;103:81-7.

102. Leong GM, Moverare S, Brce J, et al. Estrogen up-regulates hepatic expression of suppressors of cytokine signaling-2 and -3 in vivo and in vitro. Endocrinology. 2004;145:5525-31.

03. Attanasio R, Barausse M, Cozzi R. Raloxifene lowers IGF-I levels in acromegalic women. Eur J Endocrinol. 2003;148:443-8. 04. Balili I, Barkan A. Tamoxifen as a therapeutic agent in acromegaly. Pituitary. 2014;17:500-4.

105. Duarte FH, Jallad RS, Bronstein MD. Clomiphene citrate for treatment of acromegaly not controlled by conventional therapies. J Clin Endocrinol Metab. 2015;100:1863-9.

106. Imani M, Khamseh ME, Asadi P, et al. Comparison of cabergoline versus raloxifene add-on therapy to long-acting somatostatin analogue in patients with inadequately controlled acromegaly: A randomized open label clinical trial. Endocr prac. 2018;24:542-7.

107. Melmed S, Popovic V, Bidlingmaier M, et al. Safety and efficacy of oral octreotide in acromegaly: Results of a multicenter phase of oral octreotide in acromegaly: Results of a multicen
III trial. J Clin Endocrinol Metab. 2015;100:1699-1708.

108. Trainer PJ, Newell-Price JDC, Ayuk J, et al. A randomised, openlabel, parallel group phase II study of antisense oligonucleotide therapy in acromegaly. Eur J Endocrinol. 2018;179:97-108.

109. Madan A, Zhu YF, Markison S, et al. Phase I clinical trial of CRNO0808, an orally bioavailable sst2-selective, nonpeptide somatostatin biased agonist for the treatment of acromegaly: Safety, pharmacokinetics, and inhibition of GHRH-induced GH secretion. 2018. Abstr ORO6-3. Available at: www.
endocrine.org/meetings/endo-annual-meetings/abstractendocrine.org/meetings/endo-annu
details?

details? ID $=46822$ (8 October 2018).
110. Abu Dabrh AM, Asi N, Farah WH, et al. Radiotherapy versus radiosurgery in treating patients with acromegaly: A systematic review and meta-analysis. Endocr prac. 2015;21:943-56.

11. Minniti G, Jaffrain-Rea ML, Osti M, et al. The long-term efficacy of conventional radiotherapy in patients with GH-secreting pituitary adenomas. Clin Endocrinol (Oxf). 2005;62:210-16.

2. Castinetti $F$, Taieb D, Kuhn JM, et al. Outcome of gamma knife radiosurgery in 82 patients with acromegaly: Correlation with initial hypersecretion. J Clin Endocrinol Metab. 2005;90:4483-8.

113. Landolt AM, Haller D, Lomax N, et al. Octreotide may act as a radioprotective agent in acromegaly. J Clin Endocrinol Metab. 2000;85:1287-9

14. Kasaliwal R1, Sankhe SS, Lila AR, et al. Volume interpolated 3D-spoiled gradient echo sequence is better than dynamic contrast spinecho sequence for MRI detection of corticotropin secreting pituitary microadenomas. Clin Endocrinol (OXf). 2013:78:825-30.

115. Langlois F Lim DST, Yedinak CG, et al. Predictors of silent corticotroph adenoma recurrence: A large retrospective single center study and systematic literature review. Pituitary. 2018:21:32-40.

116. Dallapiazza RF, Oldfield EH, Jane JA J. Surgical management of Cushing's disease. Pituitary. 2015;18:211-16.

17. Hofmann BM, Hlavac M, Martinez R, et al. Long-term results after microsurgery for Cushing disease: Experience with 426 primary operations over 35 years. J Neurosurg. 2008;108:9-18.
8. Atkinson AB, Kennedy A, Wiggam Ml, et al. Long-term remission rates after pituitary surgery for Cushing's disease: the need for long-term surveillance. Clin Endocrinol (Oxf). 2005;63:549-59.

19. Hassan-Smith ZK, Sherlock M, Reulen RC, et al. Outcome of Cushing's disease following transsphenoidal surgery in a single center over 20 years. J Clin Endocrinol Metab. 2012;97:1194-201

120. Post FA, Soule SG, De Villiers JC, Levitt NS. Pituitary function after selective adenomectomy for Cushing's disease. Br J Neurosurg. 1995;9:41-6

21. Pecori Giraldi F, Andrioli M, De Marinis L, et al. Significant GH deficiency after long-term cure by surgery in adult patients with Cushing's disease. Eur J Endocrinol. 2007;156:233-9.

122. Zaidi HA, Penn DL, Cote DJ, Laws ER Jr. Root cause analysis of diagnostic and surgical failures in the treatment of suspected Cushing's disease. J Clin Neurosci. 2018:53:153-9.

123. Dickerman RD, Oldfield EH. Basis of persistent and recurrent Cushing disease: An analysis of findings at repeated pituitary surgery. J Neurosurg. 2002;97:1343-9.

124. Benveniste RJ, King WA, Walsh J, et al. Repeated transsphenoidal surgery to treat recurrent or residual pituitary adenoma. J Neurosurg. 2005;102:1004-12.

125. Ram Z, Nieman LK, Cutler GB Jr, et al. Early repeat surgery for persistent Cushing's disease. J Neurosurg. 1994;80:37-45.

26. Fleseriu M, Hamrahian AH, Hoffman AR, et al. American Association of Clinical Endocrinologists and American College of Endocrinology Disease State Clinical Review: Diagnosis of recurrence in Cushing disease. Endocr prac. 2016;22:1436-48.

127. Colao A, Petersenn S, Newell-Price J, et al. A 12-month phase III study of pasireotide in Cushing's disease. N Eng/ I Med. 2012;366:914-24

128. Lacroix A, Gu F, Gallardo W, et al. Efficacy and safety of oncemonthly pasireotide in Cushing's disease: A 12 month clinical trial. Lancet Diabetes Endocrinol. 2018;6:17-26.

129. Godbout A, Manavela M, Danilowicz K, et al. Cabergoline monotherapy in the long-term treatment of Cushing's disease. EurJEndocrinol.2010:163:709-16.

130. Pivonello R, De Martino MC, Cappabianca P, et al. The medical treatment of Cushing's disease: effectiveness of chronic treatment with the dopamine agonist cabergoline in patients unsuccessfully treated by surgery. I Clin Endocrinol Metab. 2009;94:223-30.

131. Vilar $L$ Naves $L A$, Azevedo MF, et al. Effectiveness of cabergoline in monotherapy and combined with ketoconazole in the management of Cushing's disease. Pituitary. 2010;13:123-9.

132. Ferriere A, Cortet C, Chanson P, et al. Cabergoline for Cushing's disease: A large retrospective multicenter study. Eur J Endocrinol. 2017;176:305-14.

133. Fleseriu M, Castinetti F. Updates on the role of adrenal steroidogenesis inhibitors in Cushing's syndrome: A focus on novel therapies. Pituitary. 2016;19:643-53.

134. Sonino N, Boscaro M, Paoletta A, et al. Ketoconazole treatment in Cushing's syndrome: experience in 34 patients. Clin Endocrinol (OXf). 1991;35:347-52.

135. Castinetti F, Morange I, Jaquet $P$, et al. Ketoconazole revisited: a preoperative or postoperative treatment in Cushing's disease. Eur J Endocrinol. 2008;158:91-9.

136. Pivonello R, De Leo M, Cozzolino A, Colao A. The Treatment of Cushing's Disease. Endocr Rev. 2015;36:385-486. Epub 2015 Jun 11

137. Castinetti F, Guignat L, Giraud P, et al. Ketoconazole in Cushing's disease: Is it worth a try? I Clin Endocrinol Metab. 2014;99:1623-30

138. Young J, Bertherat J, Vantyghem MC, et al. Hepatic safety of ketoconazole in Cushing's syndrome: Results of a Compassionate Use Programme in France. Eur J Endocrinol. 2018;178:447-58.

139. Daniel E, Aylwin S, Mustafa O, et al. Effectiveness of metyrapone in treating Cushing's syndrome: A retrospective multicenter study in 195 patients. I Clin Endocrinol Metab. 2015;100:4146-54.

140. Alexandraki KI, Grossman AB. Therapeutic strategies for the treatment of severe Cushing's syndrome. Drugs. 2016;76:447 58.

141. Fleseriu M, Biller BM, Findling JW, et al. Mifepristone, a glucocorticoid receptor antagonist, produces clinical and
metabolic benefits in patients with Cushing's syndrome. J Cli metabolic benefits in patients with C
Endocrinol Metab. 2012:97:2039-49.

142. Fleseriu M, Findling JW, Koch CA, et al. Changes in plasma ACTH levels and corticotroph tumor size in patients with Cushing's disease during long-term treatment with the glucocorticoid receptor antagonist mifepristone. J Clin Endocrinol Metab. 2014;99:3718-27.

143. Fleseriu M, Molitch ME, Gross C, et al. A new therapeutic approach in the medical treatment of Cushing's syndrome:
glucocorticoid receptor blockade with mifepristone. Endoc prac. 2013;19:313-26.

144. Cuevas-Ramos D, Lim DST, Fleseriu M. Update on medical treatment for Cushing's disease. Clin Diabetes Endocrinol. 2016;2:16

145. Feelders RA, de Bruin C, Pereira AM, et al. Pasireotide alone or with cabergoline and ketoconazole in Cushing's disease. N Eng/ J Med. 2010:362:1846-8.

146. Fleseriu M, Pivonello R, Elenkova A, et al. Safety and Efficacy of Levoketoconazole in Cushing Syndrome: Initial Results from the Phase III SONICS Study. Presented at: 18th Congress of the European Neuroendocrine Association, Wroclaw, Poland, 17-20 October 2018

147. Bertagna X, Pivonello R, Fleseriu M, et al. LCI699, a potent 


\section{Review Pituitary}

EGFR. N Engl J Med. 2010;362:2380-8.

155. Chen J, Jian X, Deng S, et al. Identification of recurrent USP48 and BRAF mutations in Cushing's disease. Nat Commun. 2018;9:3171.

156. Pecori Giraldi Ambrogio AG, Andrioli $M$ et al Potential role for retinoic acid in patients with Cushing's disease. J Clin Endocrinol Metab. 2012;97:3577-83.

157. Vilar L, Albuquerque JL, Lyra R, et al. The role of isotretinoin therapy for Cushing's disease: Results of a prospective study. therapy for Cushing's disease: Resuls

158. Langlois F, Chu J, Fleseriu M. Pituitary-directed therapies for Cushing's disease. Front Endocrinol (Lausanne). 2018;9:164

159. Lu J, Chatain GP, Bugarini A, et al. Histone deacetylase inhibitor SAHA is a promising treatment of Cushing disease. I Clin

160. Estrada J, Boronat M, Mielgo M, et al. The long-term outcome of pituitary irradiation after unsuccessful transsphenoidal surgery in Cushing's disease. N Eng/ J Med. 1997;336:172-7.

61. Mehta GU, Ding D, Patibandla MR, et al. Stereotactic radiosurgery for Cushing disease: Results of an international multicenter study. J Clin Endocrinol Metab. 2017;102:4284-91.

162. Reincke M, Ritzel K, Osswald A, et al. A critical reappraisal of bilateral adrenalectomy for ACTH-dependent Cushing's syndrome. Eur J Endocrinol. 2015;173:M23-32.

163. Tritos NA, Biller BM. Cushing's disease. Handb Clin Neurol. 2014;124:221-34.

164. Ritzel K, Beuschlein F, Mickisch A, et al. Clinical review: Outcome of bilateral adrenalectomy in Cushing's syndrome: A systematic review. I Clin Endocrinol Metab. 2013;98:3939-48.

165. Assie G, Bahurel H, Coste J, et al. Corticotroph tumor progression after adrenalectomy in Cushing's disease: A reappraisal of Nelson's syndrome. I Clin Endocrinol Metab. 2007;92:172-9.

166. Mehta GU, Sheehan JP, Vance ML. Effect of stereotactic radiosurgery before bilateral adrenalectomy for Cushing's disease on the incidence of Nelson's syndrome. J Neurosurg
2013;119:1493-7.

67. Nagesser SK, van Seters AP, Kievit J, et al. Long-term results of total adrenalectomy for Cushing's disease. World I Surg. 2000;24:108-13.

Lania A Beckers A et al 2013 European Thyroid Association guidelines for the diagnosis and treatment of thyrotropin-secreting pituitary tumors. Eur Thyroid $\downarrow$ 2013;2:76-82.

169. Malchiodi E, Profka E, Ferrante E, et al. Thyrotropin-secreting pituitary adenomas: Outcome of pituitary surgery and

7. Yamada S, Fukuhara N, Horiguchi K, et al. Clinicopathologica characteristics and therapeutic outcomes in thyrotropincharacteristics and therapeutic outcomes in thyrotropin-
secreting pituitary adenomas: A single-center study of 90 secreting pituitary adenomas: A single-cer

171. Fukuhara N, Horiguchi K, Nishioka H, et al. Short-term preoperative octreotide treatment for TSH-secreting pituitary adenoma. Endocr J. 2015;62:21-7.

172. Gatto F, Grasso LF, Nazzari E, et al. Clinical outcome and evidence of high rate post-surgical anterior hypopituitarism in a cohort of TSH-secreting adenoma patients: Might somatostatin analogs have a role as first-line therapy? Pituitary. 2015;18:583-91.

173. Kuhn JM, Arlot S, Lefebvre H, et al. Evaluation of the treatment of thyrotropin-secreting pituitary adenomas with a slow release formulation of the somatostatin analog lanreotide. J Clin Endocrinol Metab. 2000;85:1487-91.

174. Socin HV, Chanson P, Delemer B, et al. The changing spectrum of TSH-secreting pituitary adenomas: Diagnosis and management in 43 patients. Eur I Endocrinol.2003:148:433-42.

175. Mulinda JR, Hasinski S, Rose LI. Successful therapy for a mixed thyrotropin-and prolactin-secreting pituitary macroadenoma with cabergoline. Endocr prac. 1999;5:76-9.

176. Ntali G, Capatina C, Grossman A, Karavitaki N. Clinical review: Functioning gonadotroph adenomas. $\mathrm{Clin}$ Endocrinol Metab.
2014;99:4423-33.

177. Christin-Maitre S, Rongieres-Bertrand C, Kottler ML, et al. A spontaneous and severe hyperstimulation of the ovaries revealing a gonadotroph adenoma. I Clin Endocrinol Metab. 1998;83:3450-3.

178. Tashiro $\mathrm{H}_{\text {K }}$ Katabuchi $\mathrm{H}$, Ohtake $\mathrm{H}$, et al. An immunohistochemical and ultrastructural study of a folliclestimulating hormone-secreting gonadotroph adenoma occurring in a 10 -year-old girl. Med Electron Microsc. 2000;33:25-31.

179. Karapanou O, Tzanela M, Tamouridis N, Tsagarakis S. Gonadotroph pituitary macroadenoma inducing ovarian hyperstimulation syndrome: Successful response to octreotide therapy. Hormones (Athens). 2012;11:199-202.

180. Djerassi A, Coutifaris C, West VA, et al. Gonadotroph adenom in a premenopausal woman secreting follicle-stimulating hormone and causing ovarian hyperstimulation. J Clin Endocrinol Metab. 1995;80:591-4.

181. Raverot G, Burman P, McCormack A, et al. European Society of Endocrinology Clinical Practice guidelines for the management of aggressive pituitary tumours and carcinomas. Eur J Endocrinol. 2018;178:G1-24.

182. Ji Y, Vogel RI, Lou E. Temozolomide treatment of pituitary carcinomas and atypical adenomas: Systematic review of case reports. Neurooncol Pract. 2016;3:188-95.

183. Raverot G, Sturm N, de Fraipont F, et al. Temozolomide treatment in aggressive pituitary tumors and pituitary carcinomas: A French multicenter experience. J Clin Endocrinol Metab. 2010;95:4592-9.

184. Halevy C, Whitelaw BC. How effective is temozolomide for treating pituitary tumours and when should it be used? Pituitary. 2017;20:261-6.

185. Losa M, Bogazzi F, Cannavo S, et al. Temozolomide therapy in patients with agressive pituitary adenomas or carcinomas Neurooncol. 2016:126:519-25. 